\title{
DISCOVERY OF FERROPICRITES AND HIGH-MAGNESIAN ANDESITES FROM THE ERDENETSOGT FORMATION, CENTRAL MONGOLIA
}

\author{
Ganbat Erdenesaihan ${ }^{1,3^{*}}$, Akira Ishiwatari ${ }^{1,2}$ Demberel Orolmaa ${ }^{3}$, Shoji Arai ${ }^{4}$ and Akihiro Tamura ${ }^{4}$ \\ ${ }^{1}$ Department of Earth Science, Graduate School of Science, \\ Tohoku University, Sendai 980-8578, Japan \\ *E-mail:erga@igmr.mas.ac.mn \\ ${ }^{2}$ Center for Northeast Asian Studies, Tohoku University, Sendai 980-8576, Japan \\ ${ }^{3}$ Institute of Geology and Mineral Resources, Mongolian academy of Sciences, \\ Ulaanbaatar 210-351, Mongolia \\ ${ }^{4}$ Department of Earth Science, Kanazawa University, Kakuma, Kanazawa 920-1192, Japan
}

\begin{abstract}
New geochemical and petrological results are presented for greenstones from the Erdenetsogt Formation hosted by the Tsetserlegaccretionaryterranein the Hangay region, with particular emphasis on newly found picritic and andesitic rocks. Theserocksoccur mostly in the lower portion of the ErdenetsogtFormation as massive lavas, sills, and dykes closely associated with varicolored bedded ribboncherts and siltstones. The protoliths of the studied greenstones comprise (1) plume-derived tholeiitic greenstones with oceanic plateau basalt affinity, (2) arc-derived, calc-alkalineandesites. The plume-derived rocks are characterized by chemical signatures such as slight LREE enrichment similar to that of tholeiitic OIB and the existence of ferropicrite with high $\mathrm{FeO}^{*}(>14 \mathrm{wt} \%)$ and $\mathrm{MgO}(12-22 \mathrm{wt} \%)$, which is characteristic of large igneous provinces (LIPs), including oceanic plateaus. Therefore, their tholeiitic composition and high-Fe and -Ti contents require melting of the source mantle peridotite with addition of some recycled $\mathrm{Fe}$-and Ti-rich basaltic material. The andesitesare characterized by glassy texture, high $\mathrm{MgO}$ content (up to $7 \mathrm{wt} \%$ ), and significant LREE enrichment with depletion in $\mathrm{Nb}$ and resemble sanukitetypeof high-magnesian andesite (HMAs). We infer that the Hangaytholeiiticgreenstones probably represent an accreted upper section of an oceanic plateau that developed in the deep-water region of the Hangay-Henteypaleo-ocean in the Upper Silurian-LowerDevonian. The HangayHMAs may have been produced by subduction of young oceanic plate after an oceanward back-stepping of the subduction zone that was a result of the collision during the Carboniferous of the oceanic plateau and the active continental margin of the Central Mongolian Massif.
\end{abstract}

Keywords:Uyanga area in Hangay-Henteybelt, Erdenetsogt Formation in Tsetserlegterrane, oceanic plateau, ferropicrite and ferrobasalt, high-Mg andesite (HMA)

\section{INTRODUCTION}

The Central Mongolian Massif occupies a large part of the Central Asian Orogenic Belt $[2,19,26,49,50,52,53]$, or Altaids[34, 35, 51], which extends from the Ural Mountains to the Pacific Ocean and from the Siberian craton to the Tarim and Sino-Korean cratons and which formed by the accretion of island arcs, ophiolites, oceanic islands, seamounts, accretionary wedges, oceanic plateaus, and microcontinents etc. The Hangay-Hentey belt 
is located in Central Mongolia Massif and records a progressive accretionary orogeny from Middle Cambrian to the Lower Mesozoic period. In recent years, numerous oceanic crust fragments have been found and identified within this belt, especially in the Hentey region. Nevertheless, the geology and petrology of its western part (Hangay region) that comprises a Devonian-Carboniferous accretionary complex remain mostly unstudied. In the 1990s, some basaltic greenstones intercalated with siliceous, turbiditic, and terrigenous sequences were reported from the lower portion of the thick Erdenetsogt Formation ( $2200 \mathrm{~m}$ ) of the Tsetserlegterranein southern flank of Hangay Range during geological mapping of Uyanga region in scale of 1:50,000[24]. However, the geochemistry of these greenstones has not been studied in detail, except for brief descriptions by Orolmaa and Erdenesaikhan [29] and Tsukada et al. [47]. The geochemical characteristics of Middle Paleozoic greenstones are of particular interest for understanding mantle evolution, petrogenesis, and geodynamic processes in the Hangay-Henteybelt[29, 32]. To address

\section{GEOLOGY AND FIELD OCCURRENCE}

The Lower to Middle DevonianErdenetsogtFormationis distributed widely in the Hangay region as a lower portion of Hangay series and is composed predominantly of less metamorphosed, gently folded, turbidite-dominated sedimentsincludinggreenish, bluish-grey tuffaceous siltstones, claystones, mediumto fine-grained sandstones, and variously colored and bedded radiolarian ribbon chert intercalated with basaltic greenstones with minor layers of limestone. The Middle to Upper Devonian fossils reported from the sedimentary sequences of the formation [21] as well as siliceous tuff in the lower portion the formation yielded an age of $400 \mathrm{Ma}$ by $\mathrm{Sm}-\mathrm{Nd}$ dating [29].

The basaltic greenstones are exposed along the UvurUlt and Buuruljuut valleys (gold these issues, the first three authors conducted fieldwork during the summers of 2011 and 2012 around Uyangasoum.

In this paper, we report newly discovered occurrences of picritic ( $>12 \mathrm{MgO} \mathrm{wt} \%$, [23]) and andesitic greenstones from the Middle Paleozoic Tsetserlegaccretionaryterrane in central Mongolia. In western Mongolia and adjacent areas, picritic and picrodoleriticmagmatism formed in various geodynamic settings including accretionarycollision, intraplate, traff, island arc, and backarc-basin spreading during various periods ranging from Cambrian to Lower Carboniferous have been studied [17, 30, 36].

The goals of this research were to clarifythepetrogenesis of greenstones from the ErdenetsogtFormation and examine the Middle Paleozoic oceanic magmatism and subduction-accretionary history related to the crustal growth processes of the Central Asian Orogenic Belt by presenting new field geological, petrological, and geochemical data and comparison with volcanic rocks from presently well-established geologic settings.

mining sites) to the northeast of the Uyanga village and in the NariinJalgiin Range to the southeast and occurred as massive lavas, porphyritic and aphyric dykes (up to $5 \mathrm{~m}$ in thickness), hyaloclastite, and mafic tuffs and sills. We observedaconformable relationship between cherts and lavas at several localities (Fig. 1c).These founding indicate that basalts were erupted in deep ocean pelagic region. The basaltic greenstones were divided easily in the field into ferrobasalt and normal basalt by using a handy magnetic susceptibility meter. We found, for the first time in this area,picritesat two localities. The picrites found in the Buuruljuut Valley $\left(46^{\circ} 35^{\prime} 43.1^{\prime \prime}\right.$ $\mathrm{N}, 102^{\circ} 13^{\prime} 27.1^{\prime \prime} \mathrm{E}$ ) occur as olivine-rich zones with thicknesses of $20-40 \mathrm{~cm}$ at the base of massive basalticlavas outcropping with shear contact and sometimes showing gradation in 
olivine concentration (Fig. 1b), whereas the picrites found in the Uvur-Ult Valley occur as cobbles in a river bed. Another new discovery from this area is HMA sills $\left(\mathrm{N} 50^{\circ} \mathrm{W} ; 30^{\circ} \mathrm{SW}\right)$ that intrude into siltstone along the west side of the Tsetsengiin Valley $\left(46^{\circ} 31^{\prime} 13.9^{\prime \prime} \mathrm{N}\right.$, $102^{\circ} 21^{\prime} 13.3^{\prime \prime}$ E). We observed three parallel andesite sills up to $1.7 \mathrm{~m}$ thick with a distinct pinkish-green color, which contrasts with the dark-green color of the other greenstones (Fig. 1d).
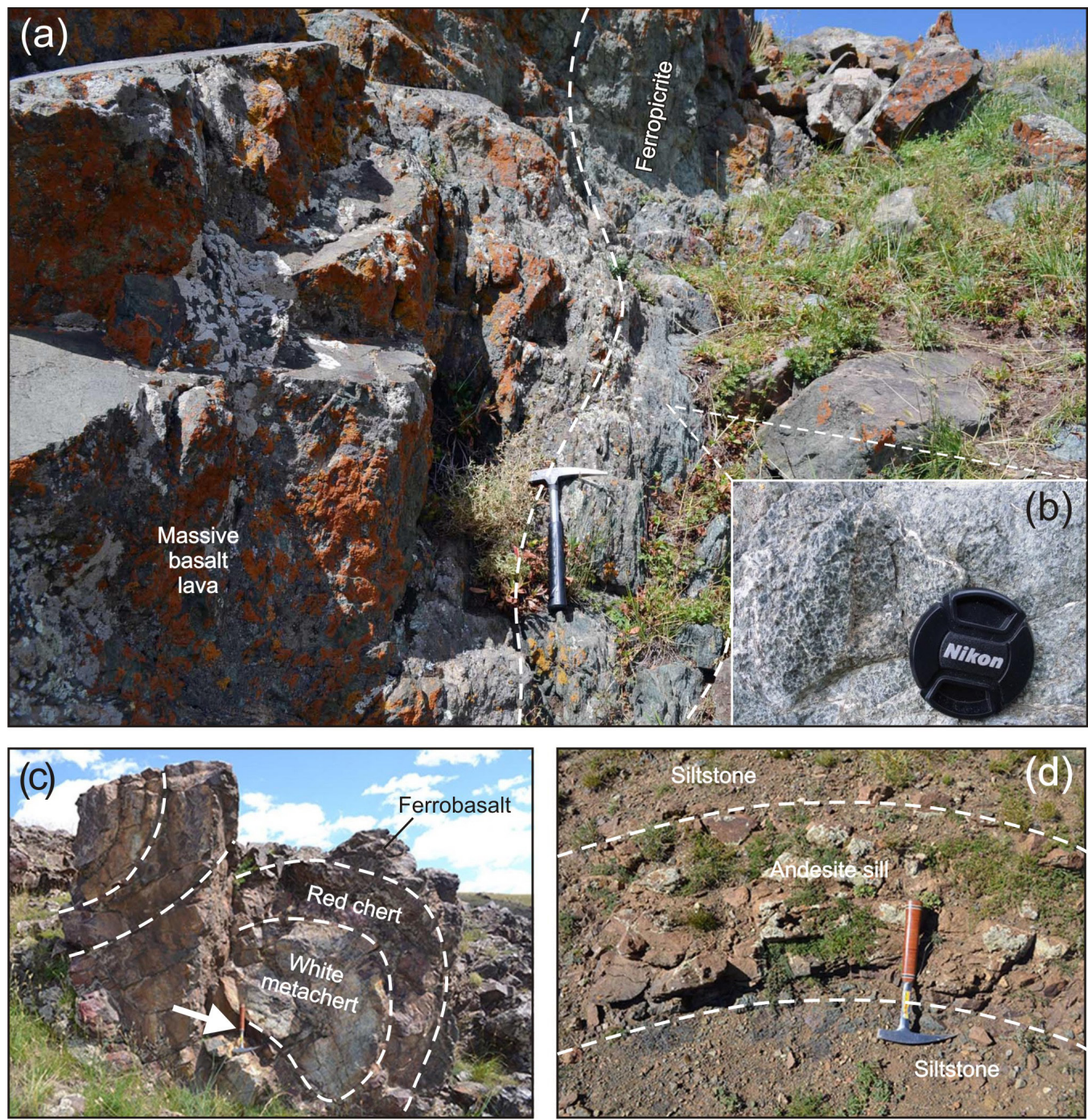

Figure 1. (a) Outcrop of basalt lava and ferropicrite at Buuruljuut (b) Ferropicrite (contains up to 32 vol.\% olivine) (c). Outcrop photo shows conformable relation between aphyricferrobasalt and multicolored chert in Tsetsengiin Valley. (d) Andesite sills intruded into siltstone. 


\section{ANALYTICAL TECHNIQUES}

Nineteen samples were selected for geochemical study based on their relative freshness under microscopic observation. Whole rock major element ( $\mathrm{Si}$, Ti, $\mathrm{Al}, \mathrm{Fe}, \mathrm{Mn}$, $\mathrm{Mg}, \mathrm{Ca}, \mathrm{Na}, \mathrm{K}$, and $\mathrm{P}$ ) and nine trace element (V, $\mathrm{Cr}, \mathrm{Ni}, \mathrm{Rb}, \mathrm{Sr}, \mathrm{Ba}, \mathrm{Y}, \mathrm{Zr}$, and $\mathrm{Nb}$ ) compositions were analyzed by $\mathrm{X}$-ray fluorescence spectroscopy at the Graduate School of Science, Tohoku University. Major element

\section{PETROGRAPHY}

The studied greenstones experienced pumpellyite-actinolite to low-temperature greenschistfacies metamorphism and composed of picrites (ferropicrites), dolerites, aphyric to porphyric basalts and andesites. Sparsely clinopyroxene-phyricdoleritesare most abundant in study area. The basalts show either aphyric, porphyricintergranular, or doleritic (ophitic) texture. The main phenocryst phases in basalts are clinopyroxene(sometimes as glomerocrysts), plagioclase, and occasional olivine (in picritic basalt). Phenocrysts of olivines and plagioclases are completely altered by chlorite, carbonate and sericite, but clinopyroxene and spinel (as inclusion

\section{RESULTS}

Whole rock geochemistry: The Hangay greenstones can be divided broadly into two major geochemical types defined by their major element distributions: tholeiitic basalt and calc-alkaline andesites. The Hangaytholeiiticbasalts exhibit two pronounced distributions in primitive mantlenormalized plots, (1) enriched-plume subtype with slight LREE enrichment similar to tholeiitic OIB (average $\mathrm{La} / \mathrm{Yb}_{\mathrm{PM}}>3.8$; Hawaiian tholeiite 3.0 and alkali basalt $\sim 8.0$;[3]) and (2) nonenriched-plumesubtypeapproximately equal to E-MORB (average $\mathrm{La} / \mathrm{Yb}_{\mathrm{PM}}<1.8$ ). Whereas calc-alkaline andesites exhibit arc-type withLREEenrichment,negativeNb compositions of well-preserved igneous minerals such as clinopyroxenes and spinels were determined by EDS at same laboratory. The REE and trace element concentrations of whole rock and clinopyroxene were determined by LA-ICP-MS at the Incubation Business Laboratory Center of Kanazawa University. The results are presented in Erdenesaihan et al., [7].

in olivine) are well preserved. Compare with basaltic greenstones the HMAs are relatively aphyric and contains less than 10 vol.\% phenocrysts, including completely altered subhedral olivine (2 vol.\%), well-preserved euhedral to subhedralmicrophenocrysts of clinopyroxene (4 vol.\%), and brown hornblende $(0.5$ vol.\%) in an aphanitic glassy groundmass. Notable relict igneous spinel inclusions were observed in both olivine and clinopyroxenemicrophenocrysts. No phenocrysts of plagioclase or bronzite were observed. The absence of plagioclase phenocrysts and a glassy nature are common features of the sanukiticHMAs.

and $\mathrm{Ta}$ anomalies, and $\mathrm{La} / \mathrm{Yb}_{\mathrm{PM}}>9.3$. They are compared with well-studied volcanic arc HMAs of Japan, seamount basalts and picrites of Hawaiian as well as traff basalts of Ontong Java, Shatsky Rise, Caribbean etc., (Fig. 2c). The first subtype is most abundant in our study area and consists of picrites (ferropicrite), basalt, dolerite, and ferrobasalts (Fig. 2a, b). Two of the five picritessampled $(>12 \mathrm{wt} \% \mathrm{MgO})$ from the Hangay region showedferropicritic compositions, as defined by Hanski and Smolkin[13] and Hanski[12], with $>14$ wt $\% \mathrm{FeO}^{*}$. The ferropicrites have been found only from traff and oceanic plateaus in the Earth so far $[9,10]$. The Hangayandesites 
have highercontents of $\mathrm{MgO}$ (up to $7 \mathrm{wt} \%$ ) compare with common andesitesandSiO (53-58wt\%), lower $\mathrm{TiO}_{2}(0.7-0.9 \mathrm{wt} \%)$. In the primitivemantle-normalized plot (Fig. 2d), in addition to the $\mathrm{Nb}$ and $\mathrm{Ta}$ depletion, the
Hangay HMAs are consistently enriched in the most incompatible elements compared with boninites but their enrichment is similar to that of Setouchi HMAs.
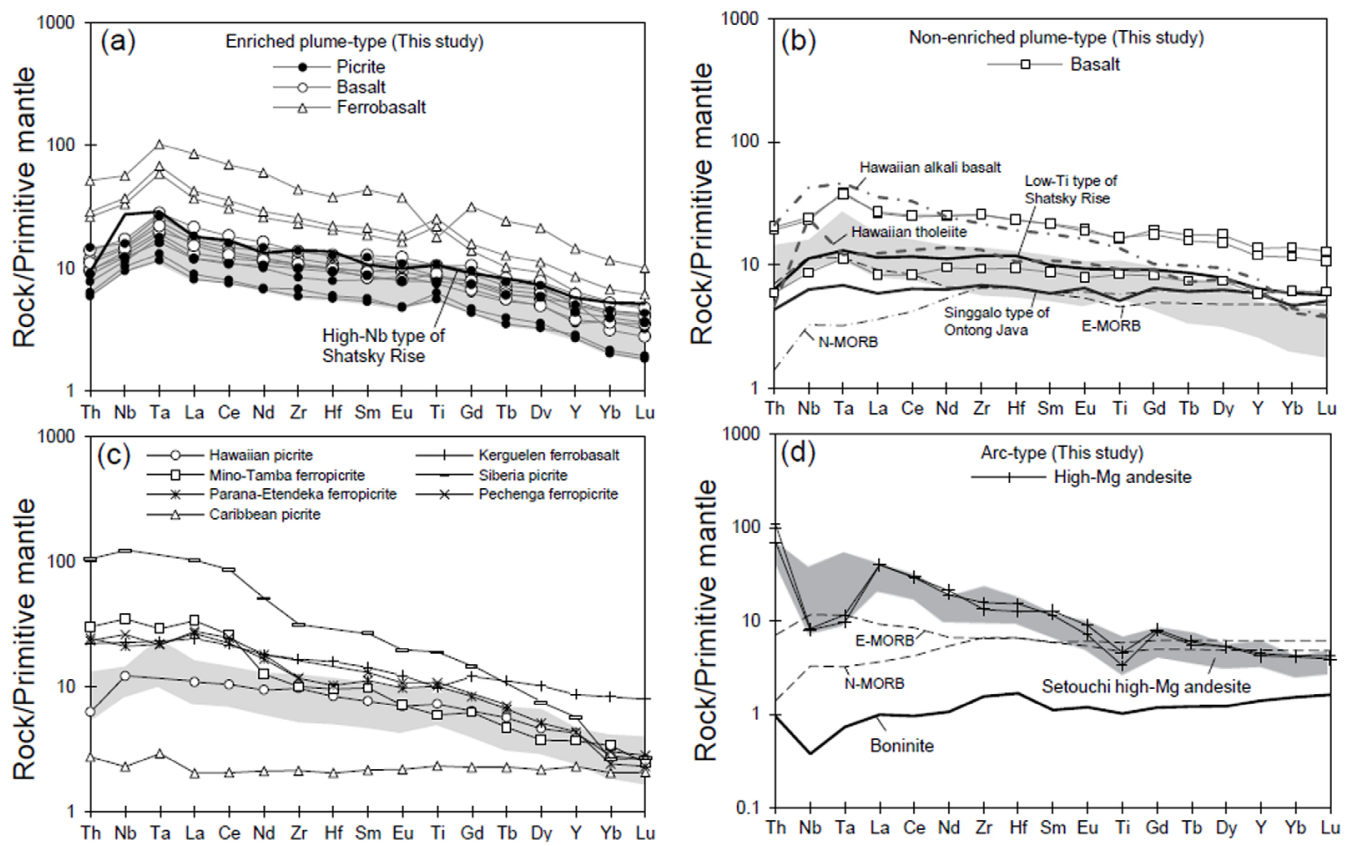

Figure 2. Primitive mantle-normalized trace element profiles of the Hangay greenstones. The pattern for the Hangay picrites is reproduced, as the shaded area, on diagrams $a, b$, and c for comparison. (a) Enriched plume-type greenstones compared with the average of high-Nb type basalts of Shatsky Rise [32]. (b) Non-enriched plume-type basalts compared with the averages of the low-Ti type of Shatsky Rise [32], Singgalo type of Ontong Java [8], and Hawaiian tholeiitic and alkali basalts [3]. (c) Data used for comparison from terrestrial tholeiitic and picritic basalts, ferrobasalts, and ferropicrites: Hawaii [28], Ontong Java [43], Kerguelen [27], Caribbean [31], Parana-Etendeka[10], Mino-Tamba[15, 16], Siberia [1], and Pechenga [12, 13]. (d) Arc-type greenstones. Data used for comparison from Setouchi and Choshi, Japan, as shaded area [14,42], and boninite from the Hahajima Seamount [25]. Primitive-mantle, enriched mid-ocean ridge basalt (E-MORB), and normal mid-ocean ridge basalt (N-MORB) values are from Sun and McDonough [38].

Mineral chemistry: The analyzed clinopyroxenes $(n=82)$ from the basaltic greenstones correspond to augite with a characteristic tholeiitic fractionation trend, whereas clinopyroxenes $(n=15)$ from the HMAs show diopsidic rim. These differences are also observed in the core-to-rim major element concentrations of the clinopyroxenes. Crystal rims in basaltic rocks are Fe- and Tienriched compared with $\mathrm{Ca}$ - and $\mathrm{Mg}$-enriched cores. In contrast, some crystal rims in andesites show $\mathrm{Fe}$ and $\mathrm{Ti}$ depletion compared with $\mathrm{Ca}$ and Mg-depleted cores. This suggests that the crystal cores in the basaltic rocks formed in Mg-rich melts, whereas their rims crystallized from more-fractionated Fe-rich magmas. In contrast, the andesitic rocks contain reversely zoned clinopyroxenephenocrysts, possibly due to magma mixing[7].

The chemical compositions of spinels were 
analyzed mostly in picrites, HMAs, and some sparsely olivine-phyric basalts. The $\mathrm{Cr} \#(=\mathrm{Cr} /$ $(\mathrm{Cr}+\mathrm{Al})$ atomic ratio) of $0.54-0.70$ of spinels in the Hangay basaltic-picritic greenstones is higher than that of spinel in MORB, resembling that of Hawaiian tholeiiticbasalt and picrite, whereas spinelsinthe $\mathrm{HMAs}(\mathrm{Cr} \#$ 0.61-0.78) arehigherin $\mathrm{Cr} \#$ and $\mathrm{Fe}^{3+}$ and

\section{DISCUSSION}

Petrogenesis of basaltic greenstones: The possible eastern extension of the Erdenetsogt Formation, as has been suggested by many researchers [5, 6, 44, 45], in the Hentey area is called the Gorkhi Formation in the Ulaanbaatar terrane, which includes similar oceanic plate assemblages of Late Silurian to Late Devonian age, as constrained by microfossils in chert[20]. The associated basaltic greenstone in this formation was studied preliminarily by Tsukada et al. [46, 47] and Safonova et al. [32]. They suggest that alkali basalts with typical ocean island basalt (OIB) affinity formed as an oceanic island or seamount in an intraplate oceanic setting of the Paleo-Asian or PaleoPacific paleo-ocean that existed between the Angara (Siberian) craton and the North China (Sino-Korean) blocks. It is interesting that our studied Hangaybasalticgreenstones present Hawaiian type tholeiitic composition only. In generally, well-studied oceanic islands display a characteristic geochemical evolution over their volcanic histories, as have beendefinedby International ocean drilling programs (ODP, IODP). The most of the mass of oceanic islands is formed during the shield-building stage, when typically up to $98 \%$ of the volcanic edifice is produced in a relatively short time span $(<5$ m.y.). During this stage, almost entirely tholeiitic or mildly alkalic basalts form from relatively large mantle melt fractions. Subsequently, alkali basalts that form by smaller degrees of partial melting may cover the shield volcano as cap rock [4, 37]. Accordingly, enriched and nonenriched subtypes defined in Hangay lower in $\mathrm{Ti}$ than spinels in the basalticpicriticgreenstonesand are closer to those in the SetouchisanukiticHMA. It implies that the HMAs weregenerated from the highly depleted magma source compared with basaltic-picritic greenstones, but lesser depleted source than boninites.

greenstones can be form within single edifice as defined for Shatsky Rise oceanic plateau basalts in Western Pasific[33] (Fig. 2a, b). On the other hand, the presence of both alkalic and tholeiithic basalts within Hangay-Hentey belt may suggest intra-oceanic magmatic heterogeneity within the Hangay-Henteypaleoocean basin in Middle Paleozoic time.These difference could be controlled by following processes: (1) increasing melt fraction and decreasing depth of melting with plume ascent [22] or (2) varying degrees of melting related to regions with different compositions in a mantle plume head $[4,16]$. For example, HREE distributions in these subtypes of basaltic greenstones indicate that the source of the non-enriched type basalts underwent a greater degree of melting than the source of the enriched type that caused its flat HREE pattern on the primitive mantle-normalized plot, with no garnet left behind in the residue (Fig. 2a, b). Althought, it is difficult to distinguish between seamount and oceanic plateau basalts based on their incompatible elements distributions, the presence of ferropicrite confirms its oceanic plateau origin. Moreover, their tholeiitic composition and high-Fe and -Ti contents require melting of the source mantle peridotite with addition of some recycled $\mathrm{Fe}$ - and Ti-rich basaltic material[9, 10, 11, 12, 13, 15, 48].

Petrogenesis of sanukitic HMAs: The Hangay HMAs are clearly distinguished from the Hangay basaltic greenstones by their glassy texture ( $<10$ vol.\% of phenocrysts) (Fig. 1f), calc-alkaliccomposition, $\mathrm{MgO}$ content (4.5-7 $\mathrm{wt} \%$ ), significant enrichment of LREEs and 
depletion of $\mathrm{Nb}$ and $\mathrm{Ta}$ and relict clinopyroxene and spinel compositions. These features confirm their arc-derived origin. Generally, HMA occurrences have been reported from the Bonin Islands, the western Pacific (boninites), the California Peninsula (bajaite), and the Setouchi belts in SW Japan (sanukite). The HangayHMAs differ from boninite $\left(\mathrm{FeO}^{*} /\right.$ $\mathrm{MgO}=0.5-0.9$ and $\mathrm{TiO}_{2}<0.5 \mathrm{wt} \%$ ) and bajaite by their higher $\mathrm{FeO} * \mathrm{MgO}(1.0-1.4)$, $\mathrm{TiO}_{2}(0.7-0.9 \mathrm{wt} \%)$, and $\mathrm{Y}$ and $\mathrm{Yb}$ contents. Furthermore, the rock is also enriched in LREEs in contrast to boninites, which show no LREE enrichment (Fig. 2d). TheHangayHMAs also do not contain phenocrysts of clinoenstatite, magnesianpigeonite, or bronzite, but boninites often do. Consequently, it is compositionally similar to the 'sanukiticHMAs' reported from the Setouchivolcanic belt of SW Japan $[39,40]$. The high abundances of Ni (45-74 ppm), Co (16-24 ppm), and $\mathrm{Cr}$ (200-300 ppm) supported by high $\mathrm{Mg \#}$ and $\mathrm{Cr} \#$ of spinel suggest that the Hangay high-Mg andesites were derived from melting of mantle wedge peridotite[7, 39, 42]. It is widely accepted that most arc magmas are derived from hydrous melting of peridotites in the mantle wedge induced by fluids released from subducted oceanic crust or overlying sediments. However, the HMA may not be generated by steady subduction but only rarely by subduction of a young and hot oceanic slab or at the initiation of subduction[18, 25, 40, 41]. 


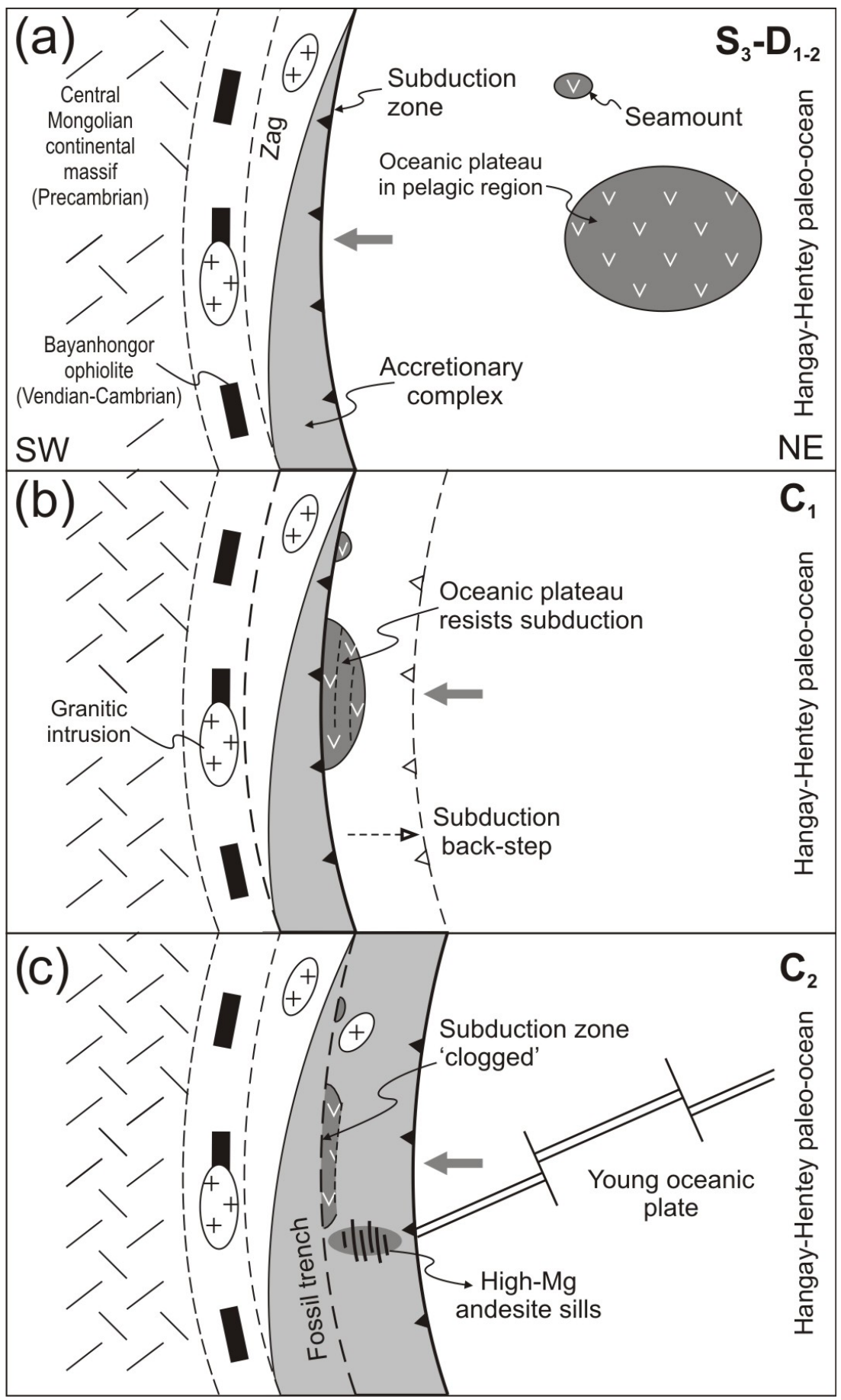

Figure 3.Tectonic reconstruction of westernmost part of the Hangay-Hentey belt from Lower Silurian to Carboniferous. (a) Oceanic plateau forms in pelagic region of the Hangay-Henteypaleo-ocean. (b) The oceanic plateau approaches to the subduction zone and obduction/jamming occurs. (c) An arc forms. 


\section{SUMMARY}

1) The lower portion of the Lower to Middle Devonian Erdenetsogt Formation in southern Hangay region consists of a mixture of chert-, siltstone-, and basaltic greenstone-dominated sequence of a typicaloceanic plate stratigraphyandon the other hand terrigenic-sedimentary and andesites of volcanic arc.

2) The first detailed geochemical and petrological study combined with field observations of the greenstones from the Hangay region revealed that the Hangay greenstones were generated in two distinct geotectonic settings and from two different magma sources: (1) deep-seated, mantle-

\section{ACKNOWLEDGEMENTS}

This work was carried out as part of the first author's doctoral research at Tohoku University and supported by an IIARE research grant. We are grateful to T. Miyamotofor his assistance and advice with XRF and SEMEDS analysis at the Department of Earth Science, Tohoku University. The first author thanks N. Hirano, S. Jargalan, and the geologypetrology laboratory members for their valuable assistance and discussions on this plume derived, high $\mathrm{Fe}$ - and $\mathrm{Mg}$ - tholeiitic greenstones that formed an oceanic plateau and (2) arc-derived calc-alkalic HMAs related to subduction of young oceanic plate.

3) The Hangay plume-derived greenstones developed as an oceanic plateau within the deep-water pelagic region of the HangayHentey paleo-ocean during Upper Silurian to Lower Devonian, whereas the Hangay HMAs were produced by non-steady subduction-zone magmatism that occurred after accretion of the oceanic plateau probably in UpperCarboniferous time.

research. A. Tsogt-Erdene and B. Bathuyag are greatly appreciated for their driving during fieldwork in Mongolia. The authors also wish to acknowledge the constructive reviews by Y. Ichiyama, M. Owada, and an anonymous reviewer in improving our manuscript. The second author acknowledges Grant-in-Aid for Scientific Research (C)-23540554 by MEXT, Japan.

\section{REFERENCES}

[1]. Arndt, N., Lehnert, K. and Vasil'ev, Y. (1995) Meimechites: highly magnesian lithospherecontaminated alkaline magmas from deep subcontinental mantle. Lithos, 34, 41-59.

[2]. Badarch, G., W. D. Cunningham, W.D. and Windley, B.F. (2002) A new terrane subdivision for Mongolia: implications for the Phanerozoic crustal growth of Central Asia. Journal of Asian Earth Sciences, 21(1), 87-110.

[3]. Best, M.G. (2003) Igneous and metamorphic petrology. pp.729, Backwell Science, Oxford.

[4]. Condie, K.C. (2001) Mantle plumes and their records in Earth history. 5, Plumes as tracer of mantle processes. pp.306. Cambrage University Press, UK.

[5]. Byamba, J., Dorjsuren, B., Dorjnamjaa, D., Tomurkhuu, D. and Makhbadar, Ts. (2009). Central Mongolian fold belt. In Geology and mineral resources of Mongolia: Tectonics lithospheric plates. Vol, IV, (Byamba, J., Badamgarav, J., Bayasgalan, A., Arvisbaatar, N., Turutanov, E.H., Dorjsuren, B., Tomurhuu, D., Dejidmaa, G., Dorjnamjaa, D., Mahbadar, Ts. and Amarjargal, A. Eds.). pp.487, Soyombo printing, Ulaanbaatar, Mongolia,199-302. (in Mongolian)

[6]. Dorjsuren, B., Bujinlkham, B., Minjin, C. and Tsukada, K. (2006) Geological settings of the Ulaanbaatar terrane in the Hangay-Hentey zone of the Devonian accretionary complex, 
Central Asian Orogenic belt. In Structural and tectonic correlation across the Central Asian Orogenic Collage: Implications for continental growth and intracontinental deformation. Abstracts with programs for the $2^{\text {nd }}$ workshop of IGCP Project-480 (Tomurhuu et al., Eds.). Institute of Geology and Mineral Recourses, Mongolian Academy of Sciences, Ulaanbaatar, Mongolia, 39-42.

[7]. Erdenesaihan, G., Ishiwatari, A., Orolmaa, D., Arai, S. and Tamura, A. (2013) Middle Paleozoic greenstones of the Hangay region, central Mongolia: Remnants of an accreted oceanic plateau and forearcmagmatism. Journal of Mineralogical and Petrological Sciences, 108(6), 303-325.

[8]. Fitton, J.G. and Godard, M. (2004) Origin and Evolution of magmas on the Ontong Java Plateau, in Origin and evolution of the Ontong Java Plateau. Geological Society, London, Special Publications, 229, 151-178.

[9]. Gibson, S.A. (2002) Major element heterogeneity in Archean to recent mantle plume starting-heads. Earth and Planetary Science Letters, 195, 59-74.

[10]. Gibson, S.A., Thompson, R.N. and Dickin, A.P. (2000) Ferropicrites: geochemical evidence for Fe-rich streaks in upwelling mantle plumes. Earth and Planetary Science Letters, 174, 355-374.

[11]. Goldstein, S.B. and Francis, D. (2008) Thepetrogenesis and mantle source of Archeanferropicrites from the Western Superior Province, Ontario, Canada. Journal of Petrology, 49 (10), 1729-1753.

[12]. Hanski, E.J. (1992) Petrology of the Pechanga ferropicrites and cogenetic, Ni-bearing gabbro-wehrlite intrusions, Kola Peninsula, Russia. Bulletin, 367, pp.192, Geological Survey of Finland.

[13]. Hanski, E.J. and Smolkin, V.F. (1989) PechengaFerropicrites and Other Early Proterozoic Picrites in the Eastern Part of the Baltic Shield. Precambrian Research, 45, 63-82.

[14]. Hoang, N., Yamamoto, T., Itoh, J.I. and Flower, M.F.J. (2009) Anomalous intra-plate high$\mathrm{Mg}$ andesites in the Choshi area (Chiba, Central Japan) produced during early stages of Japan Sea opening? Lithos, 112(3-4), 545-555.

[15]. Ichiyama, Y., Ishiwatari, A., Hirahara, Y. and Shuto, K. (2006) Geochemical and isotopic constraints on the genesis of the Permian ferropicritic rocks from the Mino-Tamba belt, SW Japan. Lithos, 89(1-2), 47-65.

[16]. Ichiyama, Y., Ishiwatari, A. and Koizumi, K. (2008) Petrogenesis of greenstones from the Mino-Tamba belt, SW Japan: Evidence for an accreted Permian oceanic plateau. Lithos, 100, 126-146.

[17]. Izokh, A.E., Vishnevskii, A.V., Polyakov, G.V. and Shelepaev, R.A. (2011) Age of picrite and picrodolerite magmatism in western Mongolia. Russian Geology and Geophysics, 52(1), 7-23.

[18]. Kamei, A., Owada, M., Nagao, T. and Shiraki, K. (2004) High-Mg diorites derived from sanukitic HMA magmas, Kyushu Island, southwest Japan arc: evidence from clinopyroxene and whole rock compositions. Lithos, 75(3-4), 359-371.

[19]. Khain, E.V., Bibikova, E.V., Kroner, A., Zhuravlev, D.Z., Sklyarov, E.V., Fedotova, A.A. and Kravchenko-Berezhnoy, I.R. (2002) The most ancient ophiolite of the Central Asian fold belt: $\mathrm{U}-\mathrm{Pb}$ and $\mathrm{Pb}-\mathrm{Pb}$ zircon ages for the Dunzhugur Complex, Eastern Sayan, Siberia, and geodynamic implications. Earth and Planetary Science Letters, 199(3), 311-325.

[20]. Kurihara, T., Tsukada, K., Otoh, S., Kashiwagi, K., Chuluun, M., Byambadash, D., Boijir, B., Gonchigdorj, S., Nuramkhan, M., Niwa, M., Tokiwa, T., Hikichi, G. and Kozuka, T. (2009) Upper Silurian and Devonian pelagic deep-water radiolarian chert from the KhangaiKhentei belt of Central Mongolia: Evidence for Middle Paleozoic subduction-accretion activity in the Central Asian Orogenic Belt. Journal of Asian Earth Sciences, 34(2), 209-225.

[21]. Kurimoto, Ch., Ichinnorov, N., Koike, T., Tungalag, F., Bayarmandal, L. (1997) The discovery of Late Devonian (Famenian) conodonts in the Bayanhongor area. Bulletin of the Geological Survey of Japan, 48(9), 487-491. 
[22]. Lassiter, J.C. and DePaolo, D.J. (1997) Plume/lithosphere interaction in the generation of continental and oceanic flood basalts: Chemical and isotopic constraints. In large igneous provinces: Continental, oceanic, and planetary flood volcanism (Mahoney, J.J. and Coffin, M.F. Eds). American Geophysical Union, Washington, D.C, 335-355.

[23]. Le Bas, M.J. (2000) IUGS Reclassification of the high-Mg and Picritic volcanic rocks. Journal of Petrology, 41(10), 1467-1470.

[24]. Lhundev, Sh., Tomurchudur, Ch., Purevdorj, Z., Baaday, D., Unurjav, L. and Ganbold, Yu. (1994) Geology and Mineral resources of the Uyanga area 1:50 000. Geological mapping and prospecting report 4756, pp, 619, Ulaanbaatar, Mongolia. (in Mongolian)

[25]. Li, Y.-B., Kimura, J.-I., Machida, S., Ishii, T., Ishiwatari, A., Maruyama, S., Qiu, H.-N., Ishikawa, T., Kato, Y., Haraguchi, S., Takahata, N., Hirahara, Y, and Miyazaki, T. (2013) High-Mg adakite and Low-Ca boninite from a Bonin fore-arc seamount: Implications for the reaction between slab melts and depleted mantle. Journal of Petrology, 54(6), 1149-1175.

[26]. Mossakovsky, A.A., Ruzhentsev, S.V., Samygin, S.G. and Kheraskova, T.N. (1994) Central Asian fold belt: Geodynamic evolution and history of formation. Geotectonics, 27, 445-474.

[27]. Neal, C.R., Mahoney, J.J. and Chazey, W.J. (2002) Mantle sources and the highly variable role of continental lithosphere in basalt petrogenesis of the Kerguelen Plateau and Broken Ridge LIP: Results from ODP Leg 183. Journal of Petrology 43(7), 1177-1205.

[28]. Norman, M.D. and Garcia, M.O. (1999) Primitive magmas and source characteristics of the Hawaiian plume: petrology and geochemistry of shield picrites. Earth and Planetary Science Letters, 168, 27-44.

[29]. Orolmaa, D. andErdenesaihan, G.(2008) Geology and geochemistry of Devonian basalts in the Hangay region. Geological Institute Transaction, 18,50-60. (in Mongolian)

[30]. Oyunchimeg, T., Izokh, A.E., Vishnevsky, A.V. and Kalugin, V.M. (2009) Isoferroplatinum mineral assemblage from the Burgastain Gol placer (Western Mongolia). Russian Geology and Geophysics, 50(10), 863-872.

[31]. Revillon, S., Arndt, N.T., Hallot, E., Kerr, A.C. and Tarney, J. (1999) Petrogenesis of picrites from the Caribbean Plateau and the North Atlantic magmatic province. Lithos 49(1-4), 1-21.

[32]. Safonova, I.Y., Utsunomiya, A., Kojima, S., Nakae, S., Tomurtogoo, O., Filippov, A.N. and Koizumi, K. (2009) Pacific superplume-related oceanic basalts hosted by accretionary complexes of Central Asia, Russian Far East and Japan. Gondwana Research, 16(3-4), 587608.

[33]. Sano, T., Shimizu, K., Ishikawa, A., Senda, R., Chang, Q., Kimura, J.-I., Widdowson, M. and Sager, W.W. (2012) Variety and origin of magmas on Shatsky Rise, northwest Pacific Ocean. Geochemistry, Geophysics, Geosystems, 13(8), Q08010, doi:10.1029/2012GC004235.

[34]. Şengor, A.M.C., Natal'in, B.A. and Burtman, V.S. (1993) Evolution of the Altaid tectonic collage and Paleozoic crustal growth in Eurasia. Nature, 364(6435), 299-307.

[35]. Şengor, A.M.C. and Natal'in, B.A. (1996) Paleotectonics of Asia: Fragments of synthesis. In The tectonic evolution of Asia (Yin, A. and Harrison, M. EDs.). pp. 486-641, Cambridge University Press.

[36]. Shkol'nik, S.I., Belichenko, V.G. and Reznitskii, L.Z. (2013) High-magnesium picritebasalt associations of the Tunka terrane (Baikal-Huvsgul region) as an indicator of the backarc basin spreading. Russian Geology and Geophysics, 54(2), 153-165.

[37]. Staudigel, H. and Clague, D.A. (2010) The geological history of deep-Sea volcanoes biosphere, hydrosphere, and lithosphere interactions. Oceanography, 23, 58-71.

[38]. Sun, S.-S. and McDonough, W.F. (1989) Chemical and isotopic systematics of oceanic basalts: implications for mantle composition and processes. Geological Society, London, Special Publications, 42(1), 313-345.

[39]. Tatsumi, Y. and Ishizaka, K. (1981) Existence of andesitic primary magma: An example from southwest Japan. Earth and Planetary Science Letters, 53(1), 124-130.

[40]. Tatsumi, Y. and Ishizaka, K. (1982) Magnesian andesite and basalt from Shodo-Shima island, southwest Japan, and their bearing on the genesis of calc-alkaline andesites. Lithos, 
15(2), 161-172.

[41]. Tatsumi, Y., Ishikawa, N., Anno, K., Ishizaka, K. and Itaya, T. (2001) Tectonic setting of high-Mg andesite magmatism in the SW Japan arc: K-Ar chronolgy of the Setouchi volcanic belt. Geophysical Journal International, 144 (3), 625-631.

[42]. Tatsumi, Y., Suzuki, T., Kawabata, H., Sato, K., Miyazaki, T., Chang, Q., Takahashi, T., Tani, K., Shibata, T. and Yoshikawa, M. (2006) The petrology and geochemistry of Oto-Zan composite lava flow on Shodo-Shima island, SW Japan: Remelting of a solidified high-Mg andesite magma. Journal of Petrology, 47(3), 595-629.

[43]. Tejada, M.L.G., Mahoney, J.J., Neal, C.R., Duncan, R.A. and Petterson, M.G. (2002) Basement geochemistry and geochronology of Central Malaita, Solomon Islands, with implications for the origin and evolution of the Ontong Java Plateau. Jourbal of Petrolology, 43, 449-484.

[44]. Tomurtogoo, O. (2012) Tectonic subdivision of Mongolian Orogenic Belts. Geological Institute Transaction, 21, 5-25. (in Mongolian)

[45]. Tomurtogoo, O. (2006) Tectonics and geodynamics of Mongolia. Mongolian science: Geological science, 53, 213-271.

[46]. Tsukada, K., Kurihara, T., Niwa, K., Otoh, S., Hikichi, G. y., Kashiwagi, K., Kozuka, T., Chuluun, M., Dorjsuren, B., Gonchigdorj, S. and Bujinlkham, B. (2006) Geochemical feature of basalt from the Gorkhi Formation, Khangay-Khentey belt, Central Mongolia. In Structural and tectonic correlation across the Central Asian Orogenic Collage: Implications for continental growth and intracontinental deformation. Abstracts with programs for the $2^{\text {nd }}$ workshop of IGCP Project-480 (Tomurhuu et al., Eds.). Institute of Geology and Mineral Recourses, Mongolian Academy of Sciences, Ulaanbaatar, Mongolia, 82-83.

[47]. Tsukada, K., Nakane, Y., Yamamoto, K., Kurihara, T., Otoh, S., Kashiwagi, K., Chuluun, M., Gonchigdorj, S., Nuramkhaan, M., Niwa, M. and Tokiwa, T. (2013) Geological setting of basaltic rocks in an accretionary complex, Khangai-Khentei Belt, Mongolia. Island Arc, $22,227-241$.

[48]. Tuff, J., Takahashi, E. and Gibson, S.A. (2005) Experimental constraints on the role of garnet pyroxenite in the genesis of high-Fe mantle plume derived melts. Journal of Petrology, 46 (10), 2023-2058.

[49]. Windley, B.F., Alexeiev, D., Xiao, W.J., Kroner, A. and Badarch, G. (2007) Tectonic models for accretion of the Central Asian Orogenic Belt. Journal of the Geological Society, 164, $31-47$.

[50]. Xiao, W.J., Han, C.M., Yuan, C., Sun, M., Lin, S.F., Chen, H.L., Li, Z.L., Li, J.L. and Sun, S. (2008) Middle Cambrian to Permian subduction-related accretionary orogenesis of Northern Xinjiang, NW China: Implications for the tectonic evolution of Central Asia. Journal of Asian Earth Sciences, 32(2-4), 102-117.

[51]. Yakubchuk, A. (2004) Architecture and mineral deposit settings of the Altaid Orogenic Collage: A revised model. Journal of Asian Earth Sciences, 23(5), 761-779.

[52]. Zonenshain, L.P., Kuz'min, M.I., Natapov, L.M., Page, B.M. and AGU Geophysical Monograph Board. (1990) Geology of the USSR: A plate-tectonic synthesis. Geodymanics Series, 21, pp.242. American Geophysical Union, Washington, D.C.

[53]. Zorin, Y.A. (1999) Geodynamics of the western part of the Mongolia-Okhotsk collisional belt, Trans-Baikal region (Russia) and Mongolia. Tectonophysics, 306(1), 33-56. 